\title{
Pengaruh varietas dan konsentrasi broth kulit pisang sebagai media alternatif pertumbuhan Aspergillus niger
}

Effect of variety and concentration of banana peel's broth as alternative media growth for Aspergillus niger.

Nucky Istiqomah Mulyawati ${ }^{1)}$, Muh. Aniar Hari Swasono ${ }^{2)}$, Deny Utomo ${ }^{2)}$

${ }^{1)}$ Mahasiswa S1 Program Studi Ilmu Teknologi Pangan, Fakultas Pertanian, Universitas Yudharta Pasuruan, Indonesia

${ }^{2)}$ Staff Pengajar Program Studi Ilmu Teknologi Pangan, Fakultas Pertanian, Universitas Yudharta Pasuruan, Indonesia email : kiki.nim03@gmail.com

Informasi artikel: Dikirim: 01/09/2019 ditinjau: $18 / 09 / 2019$ disetujui: 30/09/2019

\section{c) (i)}

Copyright (c) 2019 AGROMIX is licensed under a Creative Commons Attribution 4.0 International License.

\begin{abstract}
Banana is an influential agriculture commodity in Indonesia, for consuming the fruit or making use of the leafs and steam, with high demand of banana fruit, there's also left with tons of peel waste. Banana peel waste which usually contain cellulose (35\%-50\%), hemicellulose (25\%-30\%), and lignin (25\%$30 \%)$. The fruit peel wastes containing sugars that are metabolized by microorganisms which make the potential of microbiology growth. Aspergillus niger as one of influental fungi for industrial can be used on production of $\alpha$ Amylase. The experimental design used was Completely Randomized Design factorial with two factors. Factor I is Banana peel variety, with 4 level which contain ( Ambon Banana Peel, Kepok Banana Peel, Raja Banana Peel and Candi Banana Peel. Factor II is broth media concentration with 3 level ( 2 gr banana peel: $100 \mathrm{ml}$ Aquadest ; 4gr banana peel : 100ml Aquadest; $6 \mathrm{gr}$ banana peel : 100ml Aquadest) with the result 12 combinations with 3 repeat. The result of the streak will be observed for seven days. The result of analysis will be analyzed with Analysis of Variance (ANOVA), if there's a significant result, the analysis will be continued to $L S D$ test $5 \%$. The result of research pointed that variance of banana peel and concentration of broth media did show significant difference according to ANOVA result on day one until seven. Best variance of treatment found in V2K3 (Kepok Banana Peel with $6 \mathrm{gr} / 100 \mathrm{ml}$ concentration) resulted with average diameter reaching $55 \mathrm{~mm}$.
\end{abstract}

Keywords: alternative media growth; Aspergillus niger; banana peel

ABSTRAK: Pisang adalah salah satu komoditas pangan yang penting di Indonesia, baik untuk dimakan buahnya maupun penggunaan pada daun dan batangnya, dengan permintaan yang tinggi untuk buah pisang, maka limbah yang dihasilkan juga tinggi. Limbah kulit pisang bisa menjadi salah satu pencemaran pada tanah dan air. Kulit pisang pada umumnya mengandung cellulose $(35 \%-$ $50 \%)$, hemicellulose $(25 \%-30 \%)$, and lignin (25\% - 30\%), kulit pisang mengandung gula sederhana dan gula kompleks yang bisa dimanfaatkan dalam metabolisme mikroorganisme, membuat kulit pisang bisa digunakan sebagai salah satu media kultur bagi mikroorganisme, salah satunya adalah Aspergillus niger, salah satu fungi yang bisa digunakan dalam produksi $\alpha$-Amylase. Penelitian ini menggunakan Rancangan Acak Lengkap Faktorial yang disusun dengan dua faktor. Faktor I yaitu varietas kulit pisang yang terdiri dari 4 level (kulit pisang ambon, kulit pisang kepok, kulit pisang raja dan kulit pisang candi) dan Faktor II adalah kepekatan broth media kulit pisang yang terdiri dari 3 level ( $2 \mathrm{gr}$ kulit pisang : 100ml Aquadest ; 4gr kulit pisang : 100ml Aquadest ; 6gr kulit pisang: $100 \mathrm{ml}$ Aquadest) sehingga didapatkan 12 kombinasi dengan 3 kali ulangan. Data dari hasil pengamatan dianalisa dengan menggunakan Analysis of Variance (ANOVA), bila terdapat perbedaan yang signifikan maka dilanjutkan dengan Uji Beda Nyata Terkecil (BNT) 5\%. Hasil penelitian menunjukkan perbedaan yang signifikan, perlakuan terbaik ditemukan pada perlakuan V2K3 ( Kulit Pisang Kepok dengan konsentrasi 6gr/100ml) dengan diameter rata-rata 55 mm.

Kata kunci : Aspergillus nige; kulit pisang; media alternatif 
Sitasi: Mulyawati, N. I., Swasono, M. A. H., \& Utomo, D. (2019). Pengaruh varietas dan konsentrasi broth kulit pisang sebagai media alternatif pertumbuhan Aspergillus niger. AGROMIX, 10(2), 114-129. https://doi.org/10.35891/agx.v10i2.1578

\section{PENDAHULUAN}

Tanaman Pisang adalah salah satu komoditas pangan yang banyak ditemukan di Indonesia. Pemanfaatan Tanaman Pisang sangatlah banyak dan beragam, mulai dari batang hingga buah dari Tanaman Pisang itu sendiri. Pisang (Musa acuminata) merupakan buah yang tumbuh di daerah tropis dalam keadaan lembab. Penyebaran pisang meliputi India, Asia Tenggara, Australia bagian utara, dan daerah tropis lainnya yang bertemperatur tinggi. Jukofsky, \& Dione (2010) menyatakan bahwa buah pisang memiliki kandungan (per 100 gram) 68,9\% air, 18,50\% karbohidrat, 2,11\% lemak, $0,117 \%$ fosfor. Selain daging buah yang bisa dimanfaatkan sebagai bahan pangan dan komoditas pangan yang cukup menjual, pisang masih menyisakan limbah yang jarang dimanfaatkan Anbu et al. (2017) menyatakan bahwa limbah dari buah-buahan termasuk pisang meliputi sekitar $40 \%$ dari massa keseluruhan dari buah. Kebanyakan kulit yang telah dikupas dari buah lebih banyak dianggap limbah daripada dimanfaatkan atau bisa dimakan (Oladiji et al., 2010). Limbah dari pisang salah satunya adalah kulit pisang yang pada umumnya mengandung cellulose (35\% $50 \%)$, hemicellulose $(25 \%$ - 30\%), and lignin (25\% - 30\%) (Behera dan Ray, 2016). Kurniati (2011) menyatakan bahwa komposisi nilai gizi kulit pisang yaitu TDN 59,1\%, bahan kering
19,4\%, PK 10,91\%, serat kasar 10,60\%, abu 24,10\%, BETN 34,5\%,lemak 19,90\%, lignin 29,42\% dansilika 3,81\%. Kulit pisang kepok (Musa paradisiaca normalis) mengandung protein kasar 3,63\%, lemak kasar 2,52\%, serat kasar 18,71\%, Calsium 7,18\%, Phospor 2,06\% (Koni et al.,2006).

Kulit pisang banyak ditemukan dibuang begitu saja yang malah menyebabkan pencemaran udara karena bau dari pembusukan, hal ini juga bisa menimbulkan pertumbuhan bakteri ataupun jamur yang merugikan manusia (Ali et al., 2014). Selain itu, limbah kulit pisang ini juga berpengaruh pada air bawah tanah, penumpukan limbah kulit pisang bisa mencemari air bawah tanah. Pemanfaatan limbah kulit pisang masih sangatlah sedikit bila dibandingkan dengan limbah yang lain (Oladiji et al., 2010). Kulit buah-buahan mengandung gula sederhana yang mudah untuk dipecah oleh mikroorganisme (Saheed et al., 2013) karena kulit pisang mengandung gula sederhana dan gula kompleks yang bisa dimanfaatkan dalam metabolisme mikroorganisme. Hal ini membuat kulit pisang bisa digunakan sebagai salah satu alternatif pengganti media kultur bagi mikroorganisme. Kulit pisang yang mengandung gula sederhana dan gula kompleks bisa digunakan sebagai alternatif media kultur mikrobiologi atau bagi bakteri yang bisa dimanfaatkan baik untuk industri 
maupun bagian pangan lainnya. Dengan semakin tingginya cost yang dibutuhkan untuk membeli media kultur mikrobiologi, pemanfaatan limbah kulit pisang sebagai media kultur bisa menekan biaya yang diperlukan dan membantu dalam penelitian bagi pendidikan maupun industri (Anbu et al., 2017). Penelitian lainnya telah menemukan media alternatif seperti pati singkong (Kwoseh et al., 2012), sagu dan uwi (Tharmila et al., 2011), kentang dan umbi palmirah (Martyniuk dan Jadwiga., 2011), kacang tunggal, kacang hijau, kacang soya hitam, dan kedelei (Ravimannan et al., 2014), sayur-sayuran seperti wortel, tomat, kubis, dan labu (Deivanayaki dan Anthony., 2012).

Jamur adalah salah satu jenis mikroba yang banyak ditemukan di alam, dan menjadi salah satu ancaman terhadap komoditas agrikultur dan pangan. Salah satu jenis mikroba yang bisa dimanfaatkan dalam industri adalah Aspergillus niger. Aspergillus niger adalah salah satu jamur yang bisa digunakan dalam produksi $\alpha$-Amylase, yaitu salah satu enzim yang digunakan dalam degradasi pati (Krishna et al., 2012).

Menurut Schuster et al. (2002), Haq et al. (2004), Kareem et al. (2010) Aspergillus niger adalah salah satu jenis fungi yang sering digunakan dalam industrial karena mudah dikultur dan kemampuannya dalam menfermentasi material alami yang terjangkau dengan hasil yang tinggi. Aspergillus niger memiliki kemampuan untuk memproduksi asam sitrat (Ali et al.,2002) yang bisa digunakan sebagai pengawet dan penambah citarasa dalam industri makanan, juga memproduksi enzim amilase, protease, xelulase dan lipase (Suganthi et al., 2011) yang berperan dalam industri sirup dan fermentasi alkohol.

Pemilihan Aspergillus niger adalah karena ketahanan akan keadaan asam $(\mathrm{pH})$ yang sangat rendah membuat Aspergillus niger banyak dipilih sebagai mikroba yang membantu dalam menghasilkan $\alpha$-Amylase. Kultur mikroba sangat ditentukan oleh jenis mikroba apa yang akan ditumbuhkan dan kebutuhan gizinya, pada umumnya, mikroba jenis fungi atau jamur membutuhkan nitrogen, carbon (penghasil energi), vitamin dan faktor penumbuhan (Ravimannan et al., 2014). Meletiadis et al. (2001) menyatakan bahwa selain menyediakan wadah dan nutrisi untuk tumbuh, media kultur juga harus menyediakan ruang dan nutrisi untuk berkembang, memungkinkan fungi bisa berkembang semaksimal mungkin. Salah satu media agar yang cocok dan mendukung pertumbuhan jamur adalah PDA (Potato Dextrose Agar) yang memiliki $\mathrm{pH}$ yang rendah (pH 4,5 sampai 5,6) sehingga menghambat pertumbuhan bakteri yang membutuhkan lingkungan yang netral dengan $\mathrm{pH}$ 7,0,dan suhu optimum untuk pertumbuhan antara $25-30{ }^{\circ} \mathrm{C}$ (Kim et al., 2012). Namun, cost yang tinggi untuk media selektif membuat banyak industrial dan lembaga pendidikan lebih 
memilih media alternative yang bisa didapat dengan harga yang lebih murah (Saranraj dan Anbu, 2017).

Dengan begitu, pemanfaatan limbah kulit pisang sebagai medium kultur fungi, terutama Aspergillus niger bisa menjadi salah satu alternative yang cukup bermanfaat dalam industri, baik untuk pendidikan maupun untuk mengurangi biaya industri.

\section{METODE PELAKSANAAN}

Penelitian ini menggunakan RALF atau Rancangan Acak Lengkap Faktorial yang disusun dengan dua faktor. Faktor I yaitu varietas kulit pisang yang terdiri dari 4 level (kulit pisang ambon, kulit pisang kepok, kulit pisang raja dan kulit pisang candi) dan Faktor II adalah kepekatan broth media kulit pisang yang terdiri dari 3 level, dengan 3 kali ulangan.

Tabel 1. Desain eksperimen

\begin{tabular}{lllll}
\hline \multirow{2}{*}{ PERLAKUAN } & \multicolumn{3}{c}{ ULANGAN } \\
\cline { 3 - 5 } & & I & II & III \\
\hline V1 & K1 & U1 & U2 & U3 \\
V1 & K2 & U1 & U2 & U3 \\
V1 & K3 & U1 & U2 & U3 \\
V2 & K1 & U1 & U2 & U3 \\
V2 & K2 & U1 & U2 & U3 \\
V2 & K3 & U1 & U2 & U3 \\
V3 & K1 & U1 & U2 & U3 \\
V3 & K2 & U1 & U2 & U3 \\
V3 & K3 & U1 & U2 & U3 \\
V4 & K1 & U1 & U2 & U3 \\
V4 & K2 & U1 & U2 & U3 \\
V4 & K3 & U1 & U2 & U3 \\
\hline
\end{tabular}

\begin{tabular}{|c|c|}
\hline Keter & \\
\hline $\mathrm{V} 1 \mathrm{~K} 1=$ & Varietas kulit pisang ambon dengan konsentrasi $2 \mathrm{gr} / 100 \mathrm{ml}$ \\
\hline $\mathrm{V} 1 \mathrm{~K} 2=$ & Varietas kulit pisang ambon dengan konsentrasi 4gr/100ml \\
\hline $\mathrm{V} 1 \mathrm{~K} 3=$ & Varietas kulit pisang ambon dengan konsentrasi $6 \mathrm{gr} / 100 \mathrm{ml}$ \\
\hline $\mathrm{V} 2 \mathrm{~K} 1=$ & Varietas kulit pisang kepok dengan konsentrasi $2 \mathrm{gr} / 100 \mathrm{ml}$ \\
\hline $\mathrm{V} 2 \mathrm{~K} 2=$ & Varietas kulit pisang kepok dengan konsentrasi 4gr/100ml \\
\hline $\mathrm{V} 2 \mathrm{~K} 3=$ & Varietas kulit pisang kepok dengan konsentrasi 6gr/100ml \\
\hline $\mathrm{V} 3 \mathrm{~K} 1=$ & Varietas kulit pisang candi dengan konsentrasi $2 \mathrm{gr} / 100 \mathrm{ml}$ \\
\hline $\mathrm{V} 3 \mathrm{~K} 2=$ & Varietas kulit pisang candi dengan konsentrasi 4gr/100ml \\
\hline $\mathrm{V} 3 \mathrm{~K} 3=$ & Varietas kulit pisang candi dengan konsentrasi $6 \mathrm{gr} / 100 \mathrm{ml}$ \\
\hline V4K1 = & Varietas kulit pisang raja dengan konsentrasi $2 \mathrm{gr} / 100 \mathrm{ml}$ \\
\hline V4K2 = & Varietas kulit pisang raja dengan konsentrasi 4gr/100ml \\
\hline $\mathrm{V} 4 \mathrm{~K} 3=$ & Varietas kulit pisang raja dengan konsentrasi $6 \mathrm{gr} / 100 \mathrm{ml}$ \\
\hline
\end{tabular}

\section{Bahan}

Bahan yang digunakan dalam penelitian ini adalah: Agar media PDA (Potato Dextrose
Agar) dan YGC (Yeast Glucose

Chloramphenicol), Aquadest berasal dari laboratorium terkait, kulit pisang ambon, kulit 
pisang raja, kulit pisang candi, kulit pisang

kepok, agar tanpa rasa dan warna (Pasar

Sukorejo), dextrosa (Multi Chemical

Indotrading).

Kulit Pisang yang telah dibersihkan,

dikeringkan dan dihaluskan

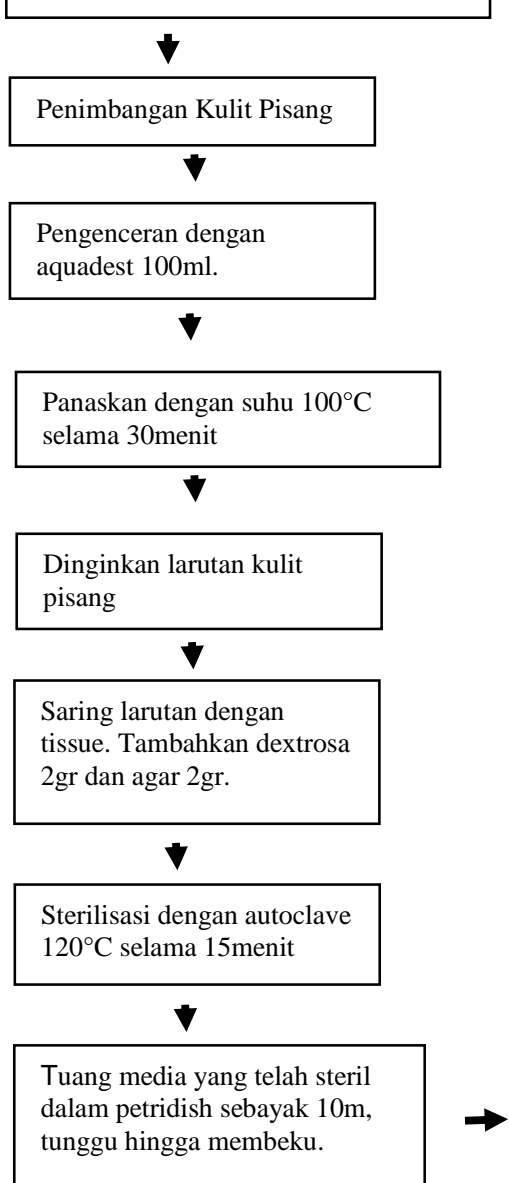

Alat

Alat yang digunakan dalam penelitian ini adalah erlenmeyer, tabung reaksi, gelas ukur, petridish pyrex, LAF, Autoclave, botol reagent (Scott Duran), hotplate, spatula, pisau, blender (Philips), kawat ose, bunsen.

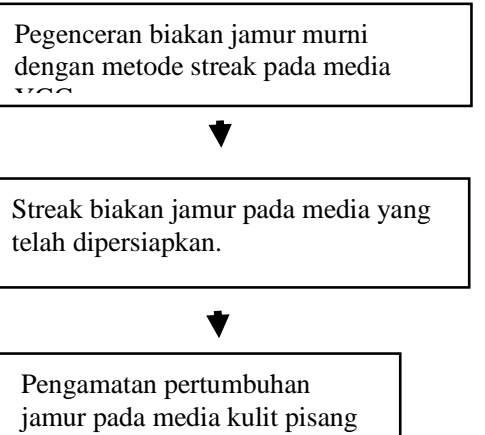

Gambar 1. Tahapan Penelitian

\section{Proses Pembuatan Media}

Pensortiran dan pencucian kulit pisang dari kotoran terkait, setelah itu kulit pisang dipotong sebesar $1 \times 1 \mathrm{~cm}$. Pengeringan kulit pisang dengan cara dijemur di bawah matahari selama $3 \times 12$ jam, dan dioven dalam suhu $60^{\circ} \mathrm{C}$ selama 3x8jam. Penghalusan kulit pisang dengan cara diblender hingga berupa bubuk. Setelah itu kulit pisang ditimbang sesuai dengan perlakuan yaitu K1 (2gr kulit pisang 
dalam $100 \mathrm{ml}$ Aquadest), K2 (4gr kulit pisang inkubator suhu $25^{\circ} \mathrm{C}$.

dalam 100ml Aquadest) dan K3 (6gr kulit pisang

\section{Analisa Data}

dalam 100ml Aquadest). Media dipanaskan

Pengumpulan data dilakukan dengan dengan suhu $100^{\circ} \mathrm{C}$ selama 30 menit dan observasi terhadap pertumbuhan dan sporulasi disaring menggunakan tisu saring. Dinginkan media broth dalam suhu ruang, tambahkan dextrosa dan agar masing-masing 2gr. Sterilisasi media dengan autoclave suhu $120^{\circ} \mathrm{C}$ selama 15 menit. Tuang media yang telah homogen dan steril dalam petridish ukuran $10 \mathrm{~cm}$, tunggu hingga media membeku.

\section{Proses Streak Biakan}

Streak biakan jamur Aspergillus niger Aspergillus niger, perhitungan pertumbuhan diameter Aspergillus niger dilakukan selama tujuh hari dengan tenggat waktu 24 jam menggunakan penggaris $\mathrm{mm}$. Analisa total gula dengan metode Luff Schoorl. Data dari hasil pengamatan dianalisa dengan menggunakan Analysis of Variance (ANOVA), bila terdapat perbedaan yang signifikan maka dilanjutkan dengan Uji Beda Nyata Terkecil (BNT) 5\%.

yang terlebih dahulu diencerkan dalam media block YGC. Inkubasi hasil streak dalam

\section{HASIL DAN PEMBAHASAN}

\section{Data Diameter Aspergillus niger Hari 1}

Tabel 2. Diameter Pertumbuhan Hari 1 (mm)

\begin{tabular}{lc}
\hline \multicolumn{1}{c}{ Perlakuan } & Diameter $(\mathbf{m m})$ \\
\hline V1K1 (Varietas kulit pisang ambon dengan konsentrasi $2 \mathrm{gr} / 100 \mathrm{ml})$ & $1,5 \mathrm{~b}$ \\
V1K2 (Varietas kulit pisang ambon dengan konsentrasi 4gr/100ml) & $4 \mathrm{c}$ \\
V1K3 (Varietas kulit pisang ambon dengan konsentrasi $6 \mathrm{gr} / 100 \mathrm{ml})$ & $5 \mathrm{c}$ \\
V2K1 (Varietas kulit pisang kepok dengan konsentrasi $2 \mathrm{gr} / 100 \mathrm{ml})$ & $0 \mathrm{a}$ \\
V2K2 (Varietas kulit pisang kepok dengan konsentrasi 4gr/100ml) & $4,5 \mathrm{c}$ \\
V2K3 (Varietas kulit pisang kepok dengan konsentrasi $6 \mathrm{gr} / 100 \mathrm{ml})$ & $6,5 \mathrm{~d}$ \\
V3K1 (Varietas kulit pisang candi dengan konsentrasi $2 \mathrm{gr} / 100 \mathrm{ml})$ & $0 \mathrm{a}$ \\
V3K2 (Varietas kulit pisang candi dengan konsentrasi $4 \mathrm{gr} / 100 \mathrm{ml})$ & $0 \mathrm{a}$ \\
V3K3 (Varietas kulit pisang candi dengan konsentrasi $6 \mathrm{gr} / 100 \mathrm{ml})$ & $0 \mathrm{a}$ \\
V4K1 (Varietas kulit pisang raja dengan konsentrasi $2 \mathrm{gr} / 100 \mathrm{ml})$ & $0 \mathrm{a}$ \\
V4K2 (Varietas kulit pisang raja dengan konsentrasi $4 \mathrm{gr} / 100 \mathrm{ml})$ & $0 \mathrm{a}$ \\
V4K3 (Varietas kulit pisang raja dengan konsentrasi $6 \mathrm{gr} / 100 \mathrm{ml})$ & $0 \mathrm{a}$ \\
\hline
\end{tabular}

Keterangan: Nilai rata-rata yang diikuti oleh huruf yang sama tidak berpengaruh nyata menurut Uji Tuckey

Hasil dari perhitungan diameter pada setiap varietas dan konsentrasi yang diuji. Aspergillus niger pada hari pertama. Hasil Perbedaan ini disebabkan oleh perbedaan analisa menunjukkan perbedaan yang signifikan kandungan nutrisi pada tiap varietas dan 
konsentrasi yang mempengaruhi pertumbuhan mold Aspergillus niger. Krishna et al., (2012) menyebutkan bahwa pertumbuhan Aspergillus niger dipengaruhi oleh oksigen, suhu, cahaya dan ketersediaan nutrisi atau substrat yang berupa karbohidrat.

Pertumbuhan dengan diameter terbesar ditemukan pada perlakuan V2K3, yaitu varietas pisang kepok dengan konsentrasi 6gr / 100ml. Diameter pertumbuhan jamur pada media V2K3 menunjukkan angka 6,5 diikuti dengan variasi V1K3, varietas pisang ambon dengan konsentrasi $6 \mathrm{gr} / 100 \mathrm{ml}$, pertumbuhan menunjukkan diameter sebesar $5 \mathrm{~mm}$, sedangkan untuk dua varietas lainnya, yaitu varietas pisang candi dan pisang raja belum

\section{Data Diameter Aspergillus niger Hari 2}

Tabel 3. Diameter Pertumbuhan Hari 2 (mm)

\begin{tabular}{|c|c|}
\hline Perlakuan & Diameter (mm) \\
\hline V1K1 (Varietas kulit pisang ambon dengan konsentrasi 2gr/100ml) & $3,5 b c$ \\
\hline V1K2 (Varietas kulit pisang ambon dengan konsentrasi 4gr/100ml) & 6,5 cde \\
\hline V1K3 (Varietas kulit pisang ambon dengan konsentrasi 6gr/100ml) & $7,5 \mathrm{fg}$ \\
\hline V2K1 (Varietas kulit pisang kepok dengan konsentrasi 2gr/100ml) & $2,5 a b$ \\
\hline V2K2 (Varietas kulit pisang kepok dengan konsentrasi 4gr/100ml) & $7 \mathrm{dfg}$ \\
\hline V2K3 (Varietas kulit pisang kepok dengan konsentrasi 6gr/100ml) & $10 \mathrm{~g}$ \\
\hline V3K1 (Varietas kulit pisang candi dengan konsentrasi 2gr/100ml) & $1 a b$ \\
\hline V3K2 (Varietas kulit pisang candi dengan konsentrasi 4gr/100ml) & $4 b c d$ \\
\hline V3K3 (Varietas kulit pisang candi dengan konsentrasi 6gr/100ml) & Oa \\
\hline V4K1 (Varietas kulit pisang raja dengan konsentrasi 2gr/100ml) & Oa \\
\hline V4K2 (Varietas kulit pisang raja dengan konsentrasi 4gr/100ml) & $3,5 b c$ \\
\hline V4K3 (Varietas kulit pisang raja dengan konsentrasi $6 \mathrm{gr} / 100 \mathrm{ml}$ ) & $2 \mathrm{ab}$ \\
\hline
\end{tabular}

Keterangan: Nilai rata-rata yang diikuti oleh huruf yang sama tidak berpengaruh nyata menurut Uji Tuckey.

Hasil dari perhitungan diameter varietas dan konsentrasi yang diuji. Perbedaan Aspergillus niger pada hari kedua ditunjukkan ini disebabkan oleh perbedaan kandungan pada Tabel 3. Hasil analisa menunjukkan nutrisi pada tiap varietas dan konsentrasi yang perbadaan yang signifikan pada beberapa mempengaruhi pertumbuhan mold Aspergillus 
niger. Pada perlakuan V4K1 dan perlakuan V3K3 belum menunjukkan pertumbuhan dari biakan jamur, sedangkan pertumbuhan baru terlihat pada perlakuan V2K1, V3K2, V4K2 dan V4K3 yang baru memasuki fase lag menuju fase akselerasi, yaitu fase dimana awal pertumbuhan jamur dan mulainya sel-sel membelah dan fase lag menjadi fase aktif.

Pada perlakuan V1K1, V1K2, V1K3, V2K2, dan V2K3 pertumbuhan jamur terlihat hampir dua kali dari diameter pada hari pertama. Perlakuan tersebut berada dalam fase eksponensial, dimana pertumbuhan jamur bergerak dengan cepat, dalam fase ini kebutuhan akan nutrisi meningkat. Diameter tertinggi masih terdapat pada perlakuan V2K3, yaitu media kulit pisang kepok dengan konsentrasi 6gr / 100ml.

\section{Data Diameter Aspergillus niger Hari 3}

Tabel 4. Diameter Pertumbuhan Hari 3 (mm)

\begin{tabular}{|c|c|}
\hline Perlakuan & Diameter $(\mathrm{mm})$ \\
\hline V1K1 (Varietas kulit pisang ambon dengan konsentrasi 2gr/100ml) & $14 \mathrm{bcd}$ \\
\hline V1K2 (Varietas kulit pisang ambon dengan konsentrasi 4gr/100ml) & $13,5 \mathrm{bcd}$ \\
\hline V1K3 (Varietas kulit pisang ambon dengan konsentrasi 6gr/100ml) & $13,5 \mathrm{bcd}$ \\
\hline V2K1 (Varietas kulit pisang kepok dengan konsentrasi 2gr/100ml) & $6 a$ \\
\hline V2K2 (Varietas kulit pisang kepok dengan konsentrasi 4gr/100ml) & $15,5 d$ \\
\hline V2K3 (Varietas kulit pisang kepok dengan konsentrasi 6gr/100ml) & $14,5 \mathrm{~cd}$ \\
\hline V3K1 (Varietas kulit pisang candi dengan konsentrasi 2gr/100ml) & $4,5 a$ \\
\hline V3K2 (Varietas kulit pisang candi dengan konsentrasi 4gr/100ml) & $7 a b$ \\
\hline V3K3 (Varietas kulit pisang candi dengan konsentrasi 6gr/100ml) & $4 a$ \\
\hline V4K1 (Varietas kulit pisang raja dengan konsentrasi 2gr/100ml) & $4 a$ \\
\hline V4K2 (Varietas kulit pisang raja dengan konsentrasi 4gr/100ml) & 9,5abcd \\
\hline V4K3 (Varietas kulit pisang raja dengan konsentrasi $6 \mathrm{gr} / 100 \mathrm{ml}$ ) & $7,5 a b c$ \\
\hline
\end{tabular}

Hasil dari perhitungan diameter Aspergillus niger pada hari ketiga. Hasil analisa menunjukkan perbedaan yang tidak terlalu signifikan dengan semua perlakuan telah menunjukkan adanya pertumbuhan dari biakan. Tiga hari adalah lama normalnya jamur untuk mencapai fase log atau fase exponential, yaitu fase dimana jamur tumbuh dengan cepat. Pertumbuhan pada beberapa perlakuan menunjukkan bahwa pertumbuhan mencapai dua kali dari hari sebelumnya. Hal ini dikarenakan laju pertumbuhan berbanding lurus dengan banyaknya nutrisi yang bisa diambil oleh jamur.

Pada perlakuan V4K1 dan perlakuan V3K3, pertumbuhan memasuki fase lag, yaitu fase penyesuaian dengan media pertumbuhan, kedua perlakuan ini memiliki waktu yang relatif lebih lama dibanding dengan perlakuan lainnya yang sudah memasuki fase akselerasi dan fase 
exponential.

Pada hari ketiga perlakuan yang menyebabkan jamur mendapatkan nutrisi yang memiliki diameter tertinggi menjadi V2K2. Hal ini bisa disebabkan dengan perbedaan nutrisi hampir sama, sehingga memiliki kecepatan pertumbuhan yang hampir sama.

\section{Data Diameter Aspergillus niger Hari 4}

Tabel 5. Diameter Pertumbuhan Hari $4(\mathrm{~mm})$

\begin{tabular}{lc}
\hline \multicolumn{1}{c}{ Perlakuan } & Diameter $(\mathbf{m m})$ \\
\hline V1K1 (Varietas kulit pisang ambon dengan konsentrasi 2gr/100ml) & $20,5 \mathrm{bcd}$ \\
V1K2 (Varietas kulit pisang ambon dengan konsentrasi 4gr/100ml) & $22 \mathrm{bcd}$ \\
V1K3 (Varietas kulit pisang ambon dengan konsentrasi 6gr/100ml) & $21 \mathrm{bcd}$ \\
V2K1 (Varietas kulit pisang kepok dengan konsentrasi $2 \mathrm{gr} / 100 \mathrm{ml})$ & $12,5 \mathrm{abc}$ \\
V2K2 (Varietas kulit pisang kepok dengan konsentrasi 4gr/100ml) & $27,5 \mathrm{~d}$ \\
V2K3 (Varietas kulit pisang kepok dengan konsentrasi 6gr/100ml) & $25 \mathrm{~cd}$ \\
V3K1 (Varietas kulit pisang candi dengan konsentrasi $2 \mathrm{gr} / 100 \mathrm{ml})$ & $10 \mathrm{ab}$ \\
V3K2 (Varietas kulit pisang candi dengan konsentrasi 4gr/100ml) & $15,5 \mathrm{abcd}$ \\
V3K3 (Varietas kulit pisang candi dengan konsentrasi $6 \mathrm{gr} / 100 \mathrm{ml})$ & $10 \mathrm{ab}$ \\
V4K1 (Varietas kulit pisang raja dengan konsentrasi $2 \mathrm{gr} / 100 \mathrm{ml})$ & $5 \mathrm{a}$ \\
V4K2 (Varietas kulit pisang raja dengan konsentrasi 4gr/100ml) & $23 \mathrm{~cd}$ \\
V4K3 (Varietas kulit pisang raja dengan konsentrasi 6gr/100ml) & $18,5 \mathrm{bcd}$ \\
\hline
\end{tabular}

Keterangan: Nilai rata-rata yang diikuti oleh huruf yang sama tidak berpengaruh nyata menurut Uji Tuckey.

Hasil analisa menunjukkan perbadaan yang tidak terlalu signifikan. Pertumbuhan jamur masih mengikuti kecepatan yang hampir sama dengan hari sebelumnya, beberapa perlakuan mulai memasuki fase exponential dan mengalami pertumbuhan hampir dua kali dari ukuran diameter sebelumnya, contohnya pada perlakuan V3K1 yang mencapai diameter 10 $\mathrm{mm}$, mengalami pertumbuhan lebih dari dua kali ukuran sebelumnya yang berada di angka 4,5 $\mathrm{mm}$. Dalam fase ini pertumbuhan berjalan dengan sangat cepat dan bergerak menuju sporulasi.

Tabel menunjukkan diameter tertinggi pada perlakuan $\mathrm{V} 2 \mathrm{~K} 2$ dengan $27,5 \mathrm{~mm}$. Tidak banyak perubahan akan perlakuan yang mengalami pertumbuhan paling tinggi, Pertumbuhan yang cukup rapid menjadi salah satu ciri bahwa jamur berada dalam fase exponential, nutrisi yang tinggi menjadi salah satu faktor utama dalam fase exponential, media kulit pisang menyediakan nutrisi yang cukup untuk pertumbuhan pada fase exponential. 


\section{Data Diameter Aspergillus niger Hari 5}

Tabel 6. Diameter Pertumbuhan Hari 5 ( $\mathrm{mm})$

\begin{tabular}{lc}
\hline \multicolumn{1}{c}{ Perlakuan } & Diameter $(\mathbf{m m})$ \\
\hline V1K1 (Varietas kulit pisang ambon dengan konsentrasi 2gr/100ml) & $26 \mathrm{abcd}$ \\
V1K2 (Varietas kulit pisang ambon dengan konsentrasi 4gr/100ml) & $27,5 \mathrm{abcd}$ \\
V1K3 (Varietas kulit pisang ambon dengan konsentrasi $6 \mathrm{gr} / 100 \mathrm{ml})$ & $30 \mathrm{cde}$ \\
V2K1 (Varietas kulit pisang kepok dengan konsentrasi $2 \mathrm{gr} / 100 \mathrm{ml})$ & $15 \mathrm{ab}$ \\
V2K2 (Varietas kulit pisang kepok dengan konsentrasi 4gr/100ml) & $36 \mathrm{e}$ \\
V2K3 (Varietas kulit pisang kepok dengan konsentrasi $6 \mathrm{gr} / 100 \mathrm{ml})$ & $35 \mathrm{de}$ \\
V3K1 (Varietas kulit pisang candi dengan konsentrasi 2gr/100ml) & $14,5 \mathrm{ab}$ \\
V3K2 (Varietas kulit pisang candi dengan konsentrasi 4gr/100ml) & $19 \mathrm{abc}$ \\
V3K3 (Varietas kulit pisang candi dengan konsentrasi $6 \mathrm{gr} / 100 \mathrm{ml})$ & $15 \mathrm{ab}$ \\
V4K1 (Varietas kulit pisang raja dengan konsentrasi $2 \mathrm{gr} / 100 \mathrm{ml})$ & $5 \mathrm{a}$ \\
V4K2 (Varietas kulit pisang raja dengan konsentrasi 4gr/100ml) & $26 \mathrm{abcd}$ \\
V4K3 (Varietas kulit pisang raja dengan konsentrasi 6gr/100ml) & $21 \mathrm{bcd}$ \\
\hline Keterangan: Nilai rata-rata yang diikuti oleh huruf yang sama tidak berpengaruh nyata menurut \\
Uji Tuckey.
\end{tabular}

Hasil dari perhitungan diameter Aspergillus niger pada hari kelima menunjukkan perbadaan yang tidak terlalu signifikan. Pertumbuhan jamur masih mengikuti kecepatan yang hampir sama dengan hari sebelumnya, meski beberapa perlakuan menunjukkan pertumbuhan di exponential. bawah $10 \mathrm{~mm}$.

\section{Data Diameter Aspergillus niger Hari 6}

Tabel 7. Diameter Pertumbuhan Hari 6 ( $\mathrm{mm})$

\begin{tabular}{lc}
\hline \multicolumn{1}{c}{ Perlakuan } & Diameter $(\mathrm{mm})$ \\
\hline V1K1 (Varietas kulit pisang ambon dengan konsentrasi 2gr/100ml) & $30 \mathrm{cde}$ \\
V1K2 (Varietas kulit pisang ambon dengan konsentrasi 4gr/100ml) & $36 \mathrm{def}$ \\
V1K3 (Varietas kulit pisang ambon dengan konsentrasi 6gr/100ml) & $37,5 \mathrm{ef}$ \\
V2K1 (Varietas kulit pisang kepok dengan konsentrasi 2gr/100ml) & $15 \mathrm{ab}$ \\
V2K2 (Varietas kulit pisang kepok dengan konsentrasi 4gr/100ml) & $47 \mathrm{f}$ \\
V2K3 (Varietas kulit pisang kepok dengan konsentrasi 6gr/100ml) & $42,5 \mathrm{f}$ \\
V3K1 (Varietas kulit pisang candi dengan konsentrasi 2gr/100ml) & $19,5 \mathrm{abc}$ \\
V3K2 (Varietas kulit pisang candi dengan konsentrasi 4gr/100ml) & $28,5 \mathrm{cde}$ \\
V3K3 (Varietas kulit pisang candi dengan konsentrasi 6gr/100ml) & $24 \mathrm{bcd}$ \\
V4K1 (Varietas kulit pisang raja dengan konsentrasi $2 \mathrm{gr} / 100 \mathrm{ml})$ & $9,5 \mathrm{a}$ \\
V4K2 (Varietas kulit pisang raja dengan konsentrasi 4gr/100ml) & $36,5 \mathrm{ef}$ \\
V4K3 (Varietas kulit pisang raja dengan konsentrasi 6gr/100ml) & $37,5 \mathrm{ef}$ \\
\hline
\end{tabular}

Keterangan: Nilai rata-rata yang diikuti oleh huruf yang sama tidak berpengaruh nyata menurut Uji Tuckey. 
Hasil dari perhitungan diameter pada perlakuan K2 dan K3 tidak memiliki Aspergillus niger pada hari keenam perbedaan yang jauh, hal ini bisa disebabkan menunjukkan perbadaan yang tidak terlalu karena perbedaan konsentrasi yang tidak signifikan. Pertumbuhan jamur terlihat mulai terlalu besar antara 4gr dan 6gr, menyebabkan melambat dibandingkan dengan hari jarak antara nutrisi yang dikandung tidak terlalu sebelumnya. Hal ini disebabkan karena besar sehingga pertumbuhan biakan memiliki berkurangnya kandungan nutrisi yang terdapat diameter yang hampir sama. Hal yang sama pada media agar block dan jamur yang mulai memasuki fase deselerasi dimana pembelahan sel mengalami pelambatan karena berkurangnya nutrisi. Perlakuan dengan hasil paling tinggi masih terdapat pada perlakuan V2K2 dengan rata-rata $47 \mathrm{~mm}$. Perlakuan V2 terlihat pada varietas V1 dan V4, dengan panjang diameter yang tidak berbeda jauh antara tiap konsentrasi. Perbandingan antara tiap varietas terlihat pada perbandingan tiga varietas lainnya dengan varietas V3, yaitu kulit pisang candi.

yaitu varietas kulit pisang kepok, pertumbuhan

\section{Data Diameter Aspergillus niger Hari 7}

Tabel 8. Diameter Pertumbuhan Hari 7 ( $\mathrm{mm}$ )

\begin{tabular}{|c|c|}
\hline Perlakuan & Diameter $(\mathrm{mm})$ \\
\hline V1K1 (Varietas kulit pisang ambon dengan konsentrasi 2gr/100ml) & $39,5 \mathrm{cde}$ \\
\hline V1K2 (Varietas kulit pisang ambon dengan konsentrasi 4gr/100ml) & 46,5 def \\
\hline V1K3 (Varietas kulit pisang ambon dengan konsentrasi $6 \mathrm{gr} / 100 \mathrm{ml}$ ) & $51 e f$ \\
\hline V2K1 (Varietas kulit pisang kepok dengan konsentrasi 2gr/100ml) & $15 a$ \\
\hline V2K2 (Varietas kulit pisang kepok dengan konsentrasi 4gr/100ml) & $52,5 e f$ \\
\hline V2K3 (Varietas kulit pisang kepok dengan konsentrasi 6gr/100ml) & $55 f$ \\
\hline V3K1 (Varietas kulit pisang candi dengan konsentrasi 2gr/100ml) & $23 a b$ \\
\hline V3K2 (Varietas kulit pisang candi dengan konsentrasi 4gr/100ml) & $28,5 a b c$ \\
\hline V3K3 (Varietas kulit pisang candi dengan konsentrasi 6gr/100ml) & $36 \mathrm{bcd}$ \\
\hline V4K1 (Varietas kulit pisang raja dengan konsentrasi $2 \mathrm{gr} / 100 \mathrm{ml}$ ) & $17 a$ \\
\hline V4K2 (Varietas kulit pisang raja dengan konsentrasi 4gr/100ml) & 46,5 def \\
\hline V4K3 (Varietas kulit pisang raja dengan konsentrasi 6gr/100ml) & 53,5 ef \\
\hline
\end{tabular}

Keterangan: Nilai rata-rata yang diikuti oleh huruf yang sama tidak berpengaruh nyata menurut Uji Tuckey.

Perhitungan diameter Aspergillus niger pada beberapa perlakuan terlihat masih pada hari ketujuh atau hari terakhir tumbuh dengan baik, dan masih dalam fase pengamatan. Hasil analisa menunjukkan eksponesial yaitu fase pertumbuhan cepat. perbadaan yang tidak terlalu signifikan. Pertumbuhan dengan hasil tertinggi pada Pertumbuhan jamur terlihat mulai melambat hari ketujuh terdapat pada perlakuan V2K3 dibandingkan dengan hari sebelumnya, meski dengan angka $55 \mathrm{~mm}$. Perlakuan V2K3 
menunjukkan bahwa jamur masih dalam fase eksponesial, kecepatan tumbuh jamur masih hampir sama dengan hari keempat maupun kelima.

Pada hari ketujuh terlihat beberapa jamur tumbuh di sekeliling streak biakan hasil dari sporulasi, hal ini menyebabkan perhitungan diameter menjadi cukup sulit. Pertumbuhan pada sekeliling biakan streak dipengaruhi oleh Aspergillus niger sebagai jenis fungi udara, sehingga spora fungi sangat mudah untuk terbang dan tumbuh di sekitar biakan.

\section{Total Gula}

Tabel 9. Data Total Gula (\%)

\begin{tabular}{|c|c|}
\hline Perlakuan & Total gula (\%) \\
\hline V1K1 (Varietas kulit pisang ambon dengan konsentrasi 2gr/100ml) & $0,405 a$ \\
\hline V1K2 (Varietas kulit pisang ambon dengan konsentrasi 4gr/100ml) & $0,785 b c$ \\
\hline V1K3 (Varietas kulit pisang ambon dengan konsentrasi 6gr/100ml) & $1,285 e f$ \\
\hline V2K1 (Varietas kulit pisang kepok dengan konsentrasi 2gr/100ml) & $0,42 a$ \\
\hline V2K2 (Varietas kulit pisang kepok dengan konsentrasi 4gr/100ml) & $0,875 \mathrm{~cd}$ \\
\hline V2K3 (Varietas kulit pisang kepok dengan konsentrasi 6gr/100ml) & $1,4 \mathrm{fg}$ \\
\hline V3K1 (Varietas kulit pisang candi dengan konsentrasi 2gr/100ml) & $0,41 a$ \\
\hline V3K2 (Varietas kulit pisang candi dengan konsentrasi 4gr/100ml) & $0,63 a b c$ \\
\hline V3K3 (Varietas kulit pisang candi dengan konsentrasi 6gr/100ml) & $1,1 \mathrm{de}$ \\
\hline V4K1 (Varietas kulit pisang raja dengan konsentrasi 2gr/100ml) & $0,57 a b$ \\
\hline V4K2 (Varietas kulit pisang raja dengan konsentrasi 4gr/100ml) & $0,785 b c$ \\
\hline V4K3 (Varietas kulit pisang raja dengan konsentrasi 6gr/100ml) & $1,625 \mathrm{~g}$ \\
\hline
\end{tabular}

Keterangan: Nilai rata-rata yang diikuti oleh huruf yang sama tidak berpengaruh nyata menurut Uji Tuckey.

Tabel 9 masing-masing menunjukkan hasil dari analisa total gula. Pertumbuhan serta perkembangan jamur umumnya sangat dipengaruhi oleh sejumlah faktor diantaranya ialah suhu, cahaya, udara, $\mathrm{pH}$ serta nutrisi seperti karbon dan nitrogen (Barnett dan Hunter, 1998), dan karbohidrat sederhana (Kelley, 1977). Pertumbuhan jamur dipengaruhi oleh beberapa hal, salah satunya adalah kadar nutrisi yang dikandung oleh media, karbohidrat merupakan substrat utama untuk metabolisme karbon pada jamur (Gandjar et al., 2006). media kulit pisang memiliki kadar karbohidrat yang mencukupi untuk pertumbuhan jamur.

Hasil perhitungan diameter pada perlakuan pada varietas V1, V2 dan V4 dengan konsentrasi yang sama memiliki hasil yang tidak berbeda jauh, masing-masing menunjukkan angka diameter $51 \mathrm{~mm}, 55 \mathrm{~mm}$ dan $54,5 \mathrm{~mm}$, hal ini juga dipengaruhi oleh kadar total gula pada masing-masing varietas yang juga tidak berbeda jauh sehingga asupan nutrisi yang diperoleh oleh Aspergillus niger juga tidak jauh berbeda, menghasilkan pertumbuhan diameter yang tidak berbeda jauh.

Perlakuan terbaik ditemukan pada perlakuan V2K3 dengan diameter tertinggi, mencapai angka $55 \mathrm{~mm}$. Pada perlakuan V2K3 kadar nutrisi yang dikandung dalam bentuk total gula adalah $1,4 \%$. Angka ini menjadi angka 
tertinggi kedua setelah perlakuan V4K3 dengan total gula 1,62\% mempengaruhi pertumbuhan jamur hingga mencapai diameter $54,5 \mathrm{~mm}$, tidak jauh berbeda dengan diameter rata-rata
V2K3 yang mencapai angka $55 \mathrm{~mm}$. Perbedaan $0,5 \mathrm{~mm}$ ini disebabkan oleh kadar nutrisi yang tidak berbeda jauh.

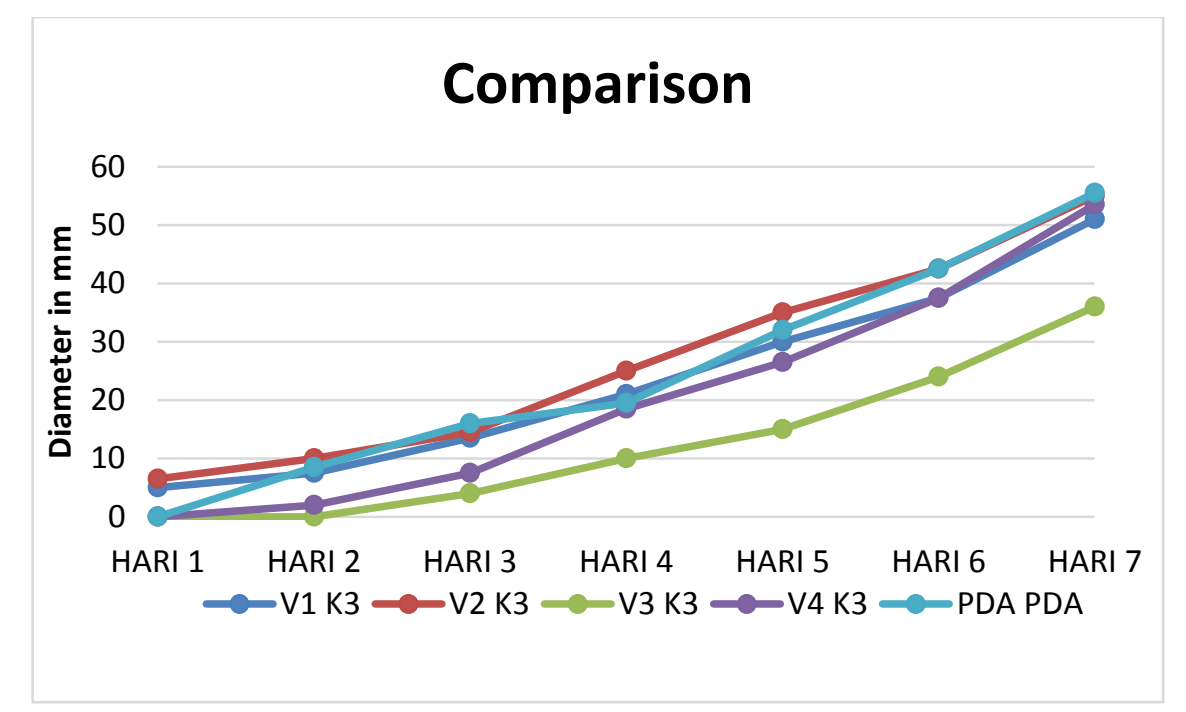

Gambar 2. Perbandingan antara tiap varietas dengan PDA.

Pada gambar 1. ditunjukkan perbandingan pertumbuhan tiap varietas dengan PDA. Terlihat dari line chart, varietas V1, V2 dan V4 memiliki laju pertumbuhan yang mirip dengan PDA, dengan jarak diameter pertumbuhan yang tidak terpaut jauh. Hal ini menunjukkan bahwa varietas $\mathrm{V} 1, \mathrm{~V} 2$ dan $\mathrm{V} 4$ dengan konsentrasi yang sama yaitu K3 memiliki hasil standar dan kecepatan pertumbuhan yang tidak berbeda jauh dengan PDA.

Pertumbuhan terbaik terdapat pada perlakuan V2K3 dengan diameter tertinggi pada hari ketujuh mencapai $55 \mathrm{~mm}$, hasil hitung diameter bisa dibandingkan dengan diameter PDA yang mencapai 55,5 mm. Menunjukkan bahwa media dengan kulit pisang memiliki nutrisi yang setara dengan PDA, dan bisa digunakan sebagai media alternatif pengganti PDA.

Perbandingan ini juga menunjukkan bahwa varietas V3 atau varietas kulit pisang candi memiliki kecepatan tumbuh yang lebih lambat dibandingkan dengan tiga varietas lainnya, hal ini disebabkan karena kandungan nutrisi yang lebih sedikit dibandingkan dengan tiga varietas lainnya.

\section{KESIMPULAN}

\section{Kesimpulan}

Varietas dan konsentrasi media kulit pisang mempengaruhi pertumbuhan Aspergillus niger dengan perlakuan terbaik yaitu V2K3 ( Varietas Kulit Pisang Kepok / Konsentrasi 6gr/100ml), dengan diameter 
mencapai $55 \mathrm{~mm}$ pada hari ketujuh.

\section{Saran}

Berdasarkan hasil penelitian pembuatan media alternatif kulit pisang dengan perbedaan varietas dan konsentrasi saran yang dapat diberikan diantaranya : 1. Perlu dikaji lebih lanjut untuk perbedaan jarak konsentrasi media agar dan varietas kulit pisang yang lebih beragam didapatkan hasil yang lebih signifikan. 2. Perlu dikaji penelitian lebih lanjut akan analisa nutrisi pendukung yang mempengaruhi pertumbuhan Aspergillus niger selain total gula.

\section{UCAPAN TERIMA KASIH}

Pada kesempatan ini penulis mengucapkan puji syukur kehadirat Allah SWT dan mengucapkan terima kasih kepada Bapak Teguh Sarwo Aji, SP., MMA selaku Dekan Fakultas Pertanian, dan Ibu Ir. Rekna Wahyuni, MP. selaku kaprodi IImu dan Teknologi Pangan sehingga dapat menyelesaikan penelitian ini.

\section{DAFTAR PUSTAKA}

Ali, S. M., Pervaiz, A., Afzal, B., Hamid, N., \& Yasmin, A. (2014). Open dumping of municipal solid waste and its hazardous impacts on soil and vegetation diversity at waste dumping sites of Islamabad city. Journal of King Saud University-Science, 26(1), 59-65.

Ali, S., Haq, I. U., Qadeer, M. A., \& Iqbal, J. (2002). Production of citric acid by
Aspergillus niger using cane molasses in a stirred fermentor. Electronic Journal of Biotechnology, 5(3), 19-20.

Anbu, S., Padma, J., Punithavalli, K., \& Saranraj, P. (2017). Fruits peel waste as a novel media for the growth of economically important Fungi. Journal of Pharmacognosy and Phytochemistry, 6(6), 426-428.

Barnett, H.L., and B.B. Hunter. (1998). Illustrated Genera of Imperfect Fungi, 4th Edition. Macmillian Publishing Company, New York, NY.218.

Behera, S. S., \& Ray, R. C. (2016). Solid state fermentation for production of microbial cellulases: recent advances and improvement strategies. International journal of biological macromolecules, 86 , 656-669.

Deivanayaki, M., \& Antony, I. P. (2012). Alternative vegetable nutrient source for microbial growth. International Journal of Biosciences (IJB), 2(5), 47-51.

Gandjar, Irawati., Sjamsuridzal Wellyzar., dan Oetari Ariyanti. (2006). Mikologi dasar dan terapan. Jakarta: Yayasan Obor Indonesia

Haq,I.,Ali,S.,Qadeer,M.A.and Iqbal,J. (2004). Citric acid production by mutants of Aspergillus niger from cane molasses. Bioresource Technology, 93(2), 125-130.

Jukofsky, \& Dione. (2010). Encyclopedia of Rainforests, Banana (Musa acuminata). Connecticut: Oryx Press.

Kareem, S. O., Akpan, I., \& Alebiowu, O. O. (2010). Production of citric acid by Aspergillus niger using pineapple waste. Malaysian Journal of 
Microbiology, 6(2), 161-165.

Kim, S. W., Jung, J. H., Lamsal, K., Kim, Y. S., Min, J. S., \& Lee, Y. S. (2012). Antifungal effects of silver nanoparticles (AgNPs) against various plant pathogenic fungi. Mycobiology, 40(1), 53-58.

Kurniati, C. (2011). Pengaruh metode pengolahan kulit pisang batu (Musa brachyarpa) terhadap kandungan NDF, $A D F$, Selulosa, Hemiselulosa, Lignindan Silika. Skripsi. Universitas Andalas. Padang.

Krishna, P. R., Srivastava, A. K., Ramaswamy, N. K., Suprasanna, P., \& D'souza, S. F. (2012). Banana peel as substrate for $\alpha$ amylase production using Aspergillus niger NCIM 616 and process optimization. IJBT, 11(3), 314-319.

Koni, TNI, Paga A, Foenay TA. (2006). Substitusi jagung dengan campuran kulit pisang dan ampas kelapa dalam ransum ayam pedaging. Laporan Hasil Penelitian Politani. Kupang.

Kwoseh, C.K., Darko. M. A., \& Adubofour, K. (2012). Cassava Starch-Agar Blend as Alternative Gelling Agent For Mycological Culture Media. Bots. J. AgricApp/Sci, 8(1), 8- 15.

Martyniuk, Stefan O., \& Jadwiga. (2011). Use of potato extract broth for culturing rootnodule bacteria. Polish Journal of Microbiology, 60 (4), 323-327.

Meletiadis, J., Meis, J. F., Mouton, J. W., \& Verweij, P. E. (2001). Analysis of growth characteristics of filamentous fungi in different nutrient media. Journal of Clinical Microbiology, 39(2), 478-484.
Oladiji, A. T., Yakubu, M. T., Idoko, A. S., Adeyemi, O., \& Salawu, M. O. (2010). Studies on the physicochemical properties and fatty acid composition of the oil from ripe plantain peel (Musa paradisiaca). African Scientist, 11(1), 7378.

Ravimannan, N., Arulanantham, R., Pathmanathan, S., \& Kularajani, N. (2014). Alternative Culture Media For Fungal Growth Using Different Formulation Of Protein Sources. Annals of Biological Research, 5(1), 36-39.

Suganthi, R., Benazir, J. F., Santhi, R., Ramesh, K.V., Anjana, H., Nitya M., Nidhiya, K. A., Kavitha, G., Lakshmi., R. (2011). Amylase Production By Aspergillus niger Under Solid State Fermentation Using Agro industrial Wastes. International Journal of Engineering Science and Technology (IJEST), 3(2), 1756-1763.

Saheed, O. K., Jamal, P., Karim, M. I. A., Alam, Z., \& Muyibi, S. A. (2013). Cellulolytic fruits wastes: a potential support for enzyme assisted protein production. Journal of Biological Sciences, 13(5), 379385.

Saranraj, P., \& Anbu, S. (2017). Utilization of agroindustrial wastes for the cultivation of industrially important fungi - a review. International Journal of Innovations in Agricultural Sciences (IJIAS), 1(2), 59- 71.

Schuster, E., Dunn-Coleman, N., Frisvad, J. C., \& Van Dijck, P. W. (2002). On the safety of Aspergillus niger-a review. Applied microbiology and biotechnology, 59(4-5), 426-435. 
Tharmila, S., Jeyaseelan, E. C., \& Thavaranjit, A. C. (2011). Preliminary Screening Of Alternative Culture Media For The Growth Of Some Selected Fungi. Archives of Applied Science Research, 3(3), 389393. 